\title{
ヘリコプターによるOD交通量調査の実施例と 静的推計OD交通量の動的解析への適用性検証
}

\author{
安藤 正幸 1 高山 純一 2 -中山 晶一朗 3 - 桑原 雅夫 4 ・㘧 正浩 5 \\ 1正会員 株式会社日本海コンサルタント 技術本部（†921-8042 石川県金沢市泉本町二丁目126番地） \\ E-mail: m-andou@nihonkai.co.jp \\ 2フェロー 金沢大学教授 理工研究域環境デザイン学系（†920-1192 石川県金沢市角間町） \\ E-mail: takayama@t.kanazawa-u.ac.jp \\ 3 正会員 金沢大学准教授 理工研究域環境デザイン学系（テ920-1192 石川県金沢市角間町） \\ E-mail: snakayama@t.kanazawa-u.ac.jp \\ 4正会員 東北大学教授 東北大学大学院情報科学研究科（干980-8579 宮城県仙台市青葉区荒巻字青葉） \\ E-mail: kuwahara@plan.civil.tohoku.ac.jp \\ 5正会員＼cjkstart株式会社日本海コンサルタント（†921-8042 石川県金沢市泉本町二丁目126番地）
}

E-mail: m-rachi@nihonkai.co.jp

\begin{abstract}
市街地内において, 踥滞緩和や交通需要マネジメントを行うためには, 各時間带の交通需要(OD交通量) を把握する必要がある。これまで交通需要を把握するためには主にナンバープレート調查が行われてきた が調查員の安全管理が課題であった。本研究では, 現地での調查員を必要としないいリコプターの空撮に よるOD交通量調査を行い, 当該調査法の特徴を整理した.

また, これまでに時間帯OD交通量の推定手法が多く研究されてきているが, 本研究では, 既存のOD交 通量推計手法により時間帯OD交通量を静的に推定し, 近年, 様々な検討に利用されている動的な解析で ある交通ミクロシミュレーションを用いて，動的な解析に対する静的に推定されたOD交通量の適用性を 検証するものである.
\end{abstract}

Key Words : OD traffic volume survey, time zone OD traffic volume estimation, DO traffic demand investigation, traffic micro simulation

\section{1. 研究の背景}

\section{(1) 研究の背景}

路計画においては，新規バイパス道路・道路拡幅事業 のような交通容量の拡大を図り，物流や移動の円滑化を 主眼とした道路交通網としての量的道路計画と，市街地 の交通需要を制御し，渋滞の緩和による生活環境の安全 性確保，快適性・利便性の向上を主眼とした質的道路計 画があると考えられる.

量的道路計画は，高度成長期より順次進められてきて おり，かなり整備が進んできている．量的道路計画では， 巨視的に地域全体をとらえ，道路網のあるべき姿を検討 するものであり, 主に主要幹線道路網の整備計画として 行われてきた. このため, 代表的な1日の交通需要にも とづき道路計画の検討が行われている. 一般に交通需要 は，全国道路街路交通情勢調査(道路交通センサス：以
降「センサス」と称す)結果や総合交通体系調査(パーソ ントリップ調查 : 以降「PT」と称す)結果によるOD交通 量を用いる場合が多い.

また一方，近年では，「人間重視の道路創造」が謳わ れており，人を中心とした安全性，利便性，および快適 性の観点からの道路整備が求められており，よりきめの 細かい道路網計画，言い換えれば質的な道路計画が求め られてきている.

質的道路計画では，主要幹線道路はもちろんのこと， その他の道路においても, 交通渋滞の解消による時間信 頼性・利便性の向上や生活道路への通過車両の排除によ る安全性・快適性の確保，ならびに道路空間機能の充実 など，道路本来が持つ質的な機能を向上させることが求 められている. したがって, 質的道路計画では, 比較的 狭範囲での計画となるため, 微視的な交通状況の把握が 課題となり，道路利用者の動向を的確に捉える必要があ 
る.たとえば，渋滞対策や生活道路空間の改善およびイ ベントなどによる道路の交通規制などの検討において， 以下の問題があると考えられる.

a)センサスOD交通量は約5年間隔，PTOD交通量は不定 期に計測されるため, 経年変化に対応できていない b)ゾーン分割が比較的大きいため, 交通量の発集地点 と発集量を正確に把握寸ることができない.

c)代表的な日の交通量であるため, 特異な状況下や特 定日の交通需要は不明である.

d)日交通量を表すものであるため, 朝夕ピークなど特 定の時間帯における交通需要が不明である.

以上のように, 既存OD交通量(センサスOD交通量, PTOD交通量)は，比較的大きな範囲を対象としているた め, 微視的な検討には不向きであり, 利用者動向をリア ルに反映するOD交通量の推計が必要となる.

\section{2. 研究の目的とその位置づけ}

都市内の渋滞対策を計画する場合は，日交通量による OD交通量では, 朝夕ピーク時における交通動向が反映 されないため, 時々刻々と変化する渋滞時のOD交通量 を把握する必要がある。このような要望に応えて，これ まで多くの時間帯OD交通量推定手法が提案されている。

本研究の目的は，ヘリコプターで上空から渋滞時の交 通状況を撮影しビデオ解析するOD交通量の計測手法に ついて，その手法や解析上の問題点を明らかにし，実務 上の有用性を検証するものである.

また，渋滞時に観測された旅行時間や茨滞長を指標と して, 静的に推定されたOD交通量の, 近年多用される 動的な解析である交通ミクロシミュレーションへの適用 性を検証するものである.

本研究の新規性は, 従来の $\mathrm{OD}$ 交通量観測がアンケー 卜による代表データの拡大やナンバープレート調査によ り行われていたが，本研究ではへリコプターを用いた空 撮により OD交通量を観測し，その実務的有用性を整理 したことである.また，静的に推定されたOD交通量の 適合性は, 単純なOD交通量の比較や交通量配分など静 的な解析による検証は多く行われているが，本研究では， 交通ミクロシミュレーションによる動的な解析を行い, 静的に推定されたOD交通量の動的な解析一の適用性を 検証したことである.

\section{3. 既存研究の整理}

\section{(1) 既存のOD交通量推計研究の整理}

OD交通量の推定は，これまで種々の研究が行われて
おり，既存 $\mathrm{OD}$ 交通量を利用するモデル(タイプA)や，観 測交通量から $\mathrm{OD}$ 交通量を与えるモデル(タイプB)がある. タイプAのモデルは，既存OD交通量を観測交通量の 值により修正するものであり, 定式化方法(目的関数及 び制約条件の組合せ)により分類される. 自動車1台1台 を区別して微視的にとらえ，各道路区間での計算交通量 が観測交通量に一致するとしてOD交通量の出現が最大 となるOD交通量分布を求めるエントロピー最大化法 ${ }^{1,2)}$ があり, この改良型として, 推計OD交通量の総和を未 知数として定式化を行う改良Willumsen法淿がある.

また，既存のOD交通量を道路区間で実測值により修 正する残差平方和最小化モデル4 ${ }^{4)}$ )がある. 飯田 9 は, リ ンクフローの計算值と観測值の残差平方和が最小となる モデルの定式化により OD交通量を推計する方法を提案 した. その後Dial法”を導入し, 経路選択問題を内生化し

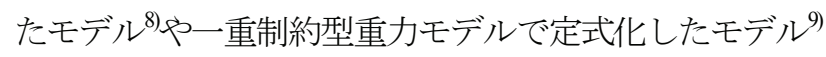
へと改良されている．近年では，残差平方和最小化モデ ルを応用した既存 $\mathrm{OD}$ 交通量の時点修正法 ${ }^{10}$ やセンサス OD交通量のBゾーンへ適用した逆推計モデル11)がある.

一方, タイプBには, 交通量観測值から重力モデル式 のパラメータを推定する手法や交差点分岐率を用いた吸 収マルコフ連鎖によるOD交通量推計手法がある.

重力モデル式のパラメータを推定する手法としては, Low $\left.{ }^{12}\right)$ がゾーン間交通量を，人口による重力モデル式の 線形回帰により解くモデルを作成し, Jensen and Nielsen ${ }^{13)}$ は, 重力モデルのパラメータをA11-or-Nothing法による計 算交通量と観測交通量の残差平方和が最小となるように 決定する手法を提案した. 更に, このモデルをHolm et $a l^{14}{ }^{14}$ 改良し, 最尤法を用いて重力モデルのパラメータ を推定する方法に発展させた。 その後, OD交通量の同 時生起確率密度が最大となる $\mathrm{OD}$ 交通量ペアを推定する モデル15)が提案された.

また，交差点分岐率による吸収マルコフ連鎖による OD交通量推計手法は，佐佐木 ${ }^{16}{ }^{10}$ ，経路選択は交差点 の分岐率に従うと仮定し，吸収マルコフ連鎖を用いたこ とに始まる，米谷・前島 ${ }^{17}$ は, 交通量の時間的な変化を 求め, 単純な交通渋滞現象一の適用について考察した. 米谷ら ${ }^{18)}$ は, 比較的短距離交通により構成される交通を 対象として, 分岐率によるマルコフ連鎖の妥当性と, OD交通量の推定を検討している，大矢 ${ }^{19}$ は，交通規制 を実施した場合の道路区間交通量の算定において, 吸収 マルコフ連鎖によるOD交通量推計法の有用性を示して いる. 西井ら ${ }^{20)}$ は, 時間帯別 $\mathrm{OD}$ 交通量を推定し, 幹線 道路の時間帯別断面交通量分布の算出方法を提案してい

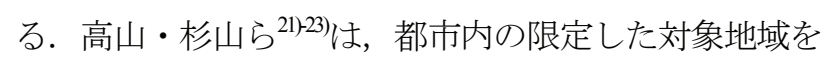
設定し，遺伝的アルゴリズム(GA)により交通を発生させ， 吸収マルコフ連鎖による経路選択を与え, OD交通量を 求める推計法を提案している. さらに, サイクル回路を 
回避する推計手法 ${ }^{24)}$ や, 経路選択にLOGITモデルを採用 した推計法 ${ }^{25}$ が提案されているほか, 吸収マルコフ連鎖 法の精度の研究26が行われている.

\section{(2) 交通ミクロシミュレーションの研究の整理}

1950年頃，交通問題へのシミュレーション技法が米国 で論じられ始めた. 当時, 交通シミュレーションの実行 方法についての多くの研究がなされ，1960年頃までには， 交通ミクロシミュレーションの可能性と有用性が一般に 認められ，大規模なシミュレーションプログラムの開発 と実証に努力が払われた，その後，非常に多くの交通ミ クロシミュレーションが開発・実行されてきた27.

前沢ら ${ }^{28}$ は，ゴールデンウィーク期間の那須高原にお ける那須IC〜大型観光施設間の交通量調査データをもと に，交通ミクロシミュレーションを用いて渋滞箇所およ び発生要因の特定を行った。この結果, 渋滞の発生箇所 は近接する変形交差点部であり，沿道の出入り交通が本 線交通に影響していることが判明した．羽藤ら ${ }^{29)}$ は，移 動体通信システムや人工衛星などによって常時更新可能 なデータベースを完備した地域防災のための都市空間情 報システムにおいて, 災害発生時に起きる車線閉塞とそ の影響を評価するケーススタディを行っている. この結 果，交通ミクロシミュレーションは災害情報システムへ の適用性が高いことを挙げている．花房ら ${ }^{30}$ は，浜松市 の中心市街地における歩行者動線を確保した交通施策に 対する周辺交通へのインパクト評価として，交通ミクロ シミュレーションにより自動車交通の円滑性確保と, 歩 行者のサービスレベルの確保の均衡点の検討を行ってい る. 高島ら ${ }^{31}$ は，交通ミクロシミュレーションを交通安 全評価への適用拡張を検討した. 検討の結果，交差点の 横断歩道の立体化，右折車線設置効果などについて合理

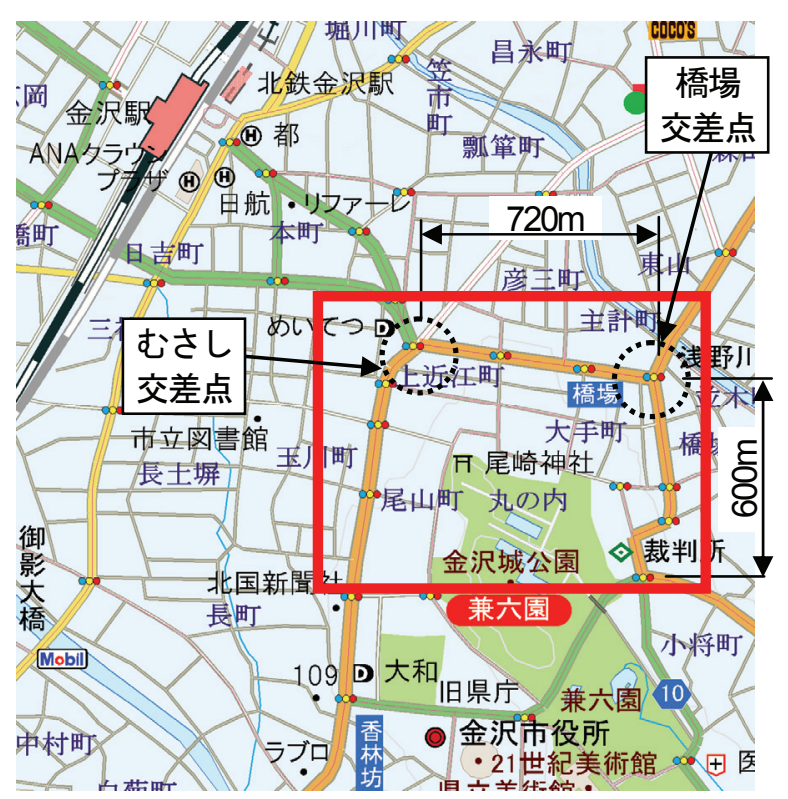

図-1 金沢市尾張町地区における調査対象エリア
的な結果が交通ミクロシミュレーションにより再現でき ること，および交通ミクロシミュレーションの適用限界 が整理できたこと，さらに交通ミクロシミュレーション の結果に高島の既存研究で示す「走行速度と車間距離の 関係による交差点の安全性評価」を適用することにより, 交通安全に関する事前評価が可能となるとしている．飯 田ら ${ }^{32}$ は，交通ミクロシミュレーションにおいて交通状 況をそのまま提示することは，モデルの透明性を高める ことを意味し，この特徵を最大限に活用し，参加型交通 計画ツールとして適用することを検討している.

以上の既存の研究結果を整理すると, 以下の事項がう かがえる. OD交通量の推計では，研究対象モデルの妥 当性について調査結果との対比を行うものの, 多様なモ デルの比較が行われておらず，どのモデルが最適である かが分からない，地域の特性により最適なモデルは一つ に決まらないものの, 例えば市街地にはどのモデルが最 も適するかを解明する必要があると考える.

また，交通ミクロシミュレーションの研究では，多様 な検討・評価の実績があり，今後の多くの交通施策に利 用されるものと考えられる. しかし，解析に用いるOD 交通量の違いによる解析結果への影響は特に研究されて いないため，OD交通量の及ぼす影響について検討する 必要があると考える.

\section{OD 交通量の計測}

\section{(1) 研究対象地域の概要とOD交通量計測の目的}

研究対象区域は, 図-1に示古石川県金沢市尾張町地区 である. 当該地区には近江町市場や大型商業施設など, 自動車交通の発生・集中する施設が多く，この地区は一 般の家屋やオフィスビルが建ち並ぶ金沢市の中心市街地 である.さらに当該地域は，交通結節の要所となってい るため，むさし交差点や橋場交差点では激しい渋滞が生 じていた. OD交通量計測は，このような渋滞状況の解 析に必要な道路利用者の需要を把握するため行った。

\section{（2） OD交通量の計測手法の検討}

OD交通量の計測にあたり，その手法として考えられ る以下の3手法について検討を行った.

・アンケートにより発生・到達点を確認する手法

・ナンバープレート調査による手法

・空撮により車両を追跡する手法

まず，アンケートによる発生・到達点の確認は，天候 に左右されず比較的少ない労力で調査が行えるメリット がある.しかし，朝の渋帯時にドライバーへのアンケー 卜用紙の配布は，配布調査員の安全確保に課題があるこ とや受領拒否・未回収が想定され，全数調査は困難であ 
る.よって, 渋滞時のOD交通量を精度良く把握するこ とは困難と考えられたため, 当該案を不採用とした.

ナンバープレート調査は，路上にビデオ機器を設置し， 車両のナンバープレートの自動読み取りと調查員による ナンバープレートの読み上げ・録音を併用する手法を検 討した.

この手法は，天候に左右されず比較的安全に計測が行 えるが，4車線道路においては第2車線を走行する車両の ナンバープレートが第1車線の車両と交錯し判読が困難 となる．このため，道路を横断する門型の支柱に撮影機 器を設置する必要があるが, 門型支柱の設置が困難であ ること，また，渋滞時であるため車両間隔が狭く，大型 車の後続車のナンバープレートの読み取り精度が悪いこ とが懸念された. さらに，調査員によるナンバープレー トの読み上げ・録音においても約5秒に1台が通過するた め，読み上げが間に合わないことが事前調査で確認され た. 以上の検討結果とナンバープレート調査による個人 情報への抵抗も懸念されたため，当該案を不採用とした。

空撮による車両の追跡は，ヘリコプターを当該地区の $1,200 \mathrm{~m}$ 上空でホバーリングし, 搭載したハイビジョンカ メラで交通状況を撮影するものである. データの集計は, 撮影したビデオを映像処理し，OD交通量として計測し， 集計したものである.

この手法は，地上における調査員は不要であるが，へ リコプターの操作の安全性や雲により地上が見えないこ とがあるため，天候に大きく左右される．また，事前調 查を行った結果, ヘリコプターが風に流されるため, 小 刻みに操作する必要があり, パイロットへの負担が大き く撮影時間は1時間が限界であった。ビルに隠れる車両 を極力低減するため, ヘリコプターを2機使用するもの とし，ヘリコプターのチャーターと撮影料金は約 75 万円 /時間とかなり高額となったが，当該案を採用し調査を 行った. 調査の概要を表-1に示寸.

\section{(3) 調査結果の集計方法}

調査結果の集計方法は, 次の2案を検討した.

\section{a) ビデオを1秒ごとの写真に変換し，写真により車両 を追跡する案}

当該案は，静的な作業であり比較的容易であるが，試 験的に事前調査の集計作業を行ったところ，車線変更や 追い越しおよび交差点での右左折があった場合，対象車 両を取り違える可能性があることが判明した。 したがっ て，集計精度に課題が残るため，当該案を不採用とした。 b) ビデオ中の車両を直接視認(目視)で追跡する案

当該案は, ビデオを再生しながら, 車両一台一台を目 視により追跡する方法であり，動的であるため計測に集 中力が必要である. しかし, 対象車両を取り違えても巻 き戻しにより, 再確認が可能であるため, 集計精度が担
表-1 金沢市尾張町地区における調査の概要表

\begin{tabular}{|l|l|}
\hline 調査日 & 調查日:平成22年9月30日(木) \\
\hline 調査時間 & 午前7時50分〜午前8時50分(1時間) \\
\hline 調查区域 & 石川県金沢市尾張町地区 \\
\hline 調査地点 & $\mathrm{A}=43.2 \mathrm{ha}(720 \mathrm{~m} \times 600 \mathrm{~m})$ \\
\hline 調查方法 & ヘリコプター2機によるビデオ撮影 \\
\hline
\end{tabular}

表-2 金沢市尾張町地区における調査の概要表

\begin{tabular}{|l|c|c|c|}
\hline 発地点 & $\begin{array}{c}\text { 着地点 } \\
\text { 地区内 }\end{array}$ & $\begin{array}{c}\text { 尾張町 } \\
\text { 地区外 }\end{array}$ & 合計 \\
\hline 尾張町地区内 & 313 & 1,010 & 1,323 \\
\hline 尾張町地区外 & 1,571 & 5,221 & 6,792 \\
\hline 合計 & 1,884 & 6,231 & 8,115 \\
\hline
\end{tabular}

総発生交通量 $($ を含む $)=8,294$ 台 $/ \mathrm{h}$

集計率 $=8,115 / 8,294=97.8 \%$

保できる. よって，当該案を採用した．

計測はビデオをコピーし， 3 班 $\times 4$ 人体制 $\times 15$ 日間で $\mathrm{OD}$ 交通量の集計作業を行った．集計は，車両が発生(流 入)した時点で当該車両を追跡し, 車種(小型・大型), 発 生地点と時刻・通過地点および到達地点と時刻を記録し た. また, 別班により各交差点の方向別交通量を10分単 位で集計した。

\section{（4）観測OD交通量データの整理}

OD交通量データの整理において，録画時間が1時間で あるため, 車両の発生地点は確認されたが，到達地点以 前に録画が終了している場合や，開始時刻に既に発生し ており発生地点が不明な車両は, 集計から削除した。

表-2に示寸とおり, 総発生交通量は8,294台/hであった が，発生・到着地点が不明な車両は179台/hであり，発 生・到着地点が確認された車両は8,115台/んであった．よ って, 集計率は $97.8 \%$ となり, ほぼ現状交通量の全量を 捉えており，観測OD交通量に有意な影響を与えないも のと考えられる.ただし，この発生・到着地点が不明な 車両は，地上て観測するナンバープレートマッチング法 においても同様に存在することになり，正規の観測時間 帯の前後数分間については, 必ず欠損データとなる. よ って, 必要に応じて観測対象とする時間帯を考慮して, 空撮時間の設定を行うことが必要である.

\section{（5）空撮により車両を追跡する手法の考察}

本研究では, ヘリコプター空撮によるOD交通量の計 測を行ったが，この手法の特徴を以下に示す.

\section{a) 空撮によるOD交通量調査方法の長所}

・地上での作業員を要しないため, 安全性は高い.

・調査は比較的容易である.

・車両の発生・到達地点が明確である.

・ほぼ全数の交通を捉えることができる. 
・走行状態(経路・渋滞状況・速度など)が確認できる.

b) 空撮によるOD交通量調査方法の短所

・細街路(ビル間)走行車両確認のため撮影範囲が狭い.

- 天候に左右される(雨天・曇天は不可).

・撮影時間が短い(1時間程度).

・夜間は観測できない.

・ヘリコプターのチャーターと撮影費用が高額である.

・調查結果の集計に多大な労力と費用を要する.

\section{（6）ヘリコプター空撮によるOD交通量調査の有用性}

ヘリコプター空撮によるOD交通量調査は, 比較的容 易にかつ安全に行うことが可能であり, 現況交通のほぼ 全数を捉えることができる．また，発生・到着地点が明 確で発生・到達時刻が秒単位で把握できるため, 時間的 変化を捉えた精度の高いOD交通量が得られる。ささらに, 車両の走行経路や旅行速度及び渋滞状況など交通状況も 把握できる. よって, ヘリコプター空撮によるOD交通 量調査は実務的に有用であると考える.

ただし，ヘリコプター空撮によるOD交通量調査には 限界があるため, 次に示す条件を満たすOD交通量調査 においてのみ適用可能である。

・観測範囲が比較的狭い範囲であること(約20ha機).

・観測時間が短いこと(1時間程度).

・調査時間帯は, ヘリコプターが運航できる時間帯 (日の出から日没までの時間帯)で, しかもホバーリ ングか可能な風のない日中の時間帯であること.

(晴天の場合は, ビデオ画像が読みにくいので, で きれば晴天時が望ましい)

・調査結果の集計に多大な時間と労力が必要であり, 集計期間と労力が確保されていること.

また, 当該調査の実施にあたっては, 関係機関への周 知を図る必要がある.

なお, 調査結果の集計に多大な労力・費用を要したた め, 今後の課題として, 画像処理ソフト(動画内の特定 点を追跡するソフト)の開発し, 迅速化と省力化及びコ スト削減が望まれる.

\section{5. 推定OD交通量の動的解析への適用性の検証}

\section{(1) 検討の背景と目的}

一般に，特定の日時における詳細なOD交通量は不明 である.このため, 先述するへリコプター空撮による OD交通量調査やナンバープレート調查など多大な費用 と労力を投じて OD交通量を計測する必要がある。しか し，このような費用・労力を削減するため，これまで特 定の時刻におけるOD交通量を, 静的・動的に推定する 研究が行われてきた.
また，近年ではこれまでの静的な交通解析ではなく， 交通状況の時間的変化をリアルに再現する交通ミクロシ ミュレーションによる動的な解析が求められている.

このような背景を踏まえ, 本研究では比較的計算が容 易な静的なOD交通量推計モデルを用いて，動的解析に 対する再現性を検証し, 静的OD推計モデルの動的解析 への適用性を検討するものである.

\section{(2) 研究の流れ}

以下に研究の流れを示寸.

a) 既存のセンサスOD交通量(H17観測)およびPTOD交通 量(H19観測)から観測年における渋滞時のOD交通量 を推定する.

b) 推定された渋滞時 $\mathrm{OD}$ 交通量に対して, 残差平方和 最小化モデルを用いて，現時点(H22)における渋滞時 OD交通量を推定する。

c) また，観測された交差点分岐率から，GA吸収マル コフ連鎖によるOD交通量推計手法により渋滞時 $\mathrm{OD}$ 交通量を推定する.

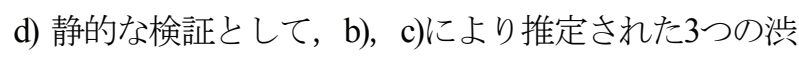
滞時OD交通量と観測OD交通量の単純比較や静的な 交通量配分によるリンク交通量の相関を検証する.

e) 観測された渋滞時OD交通量を用いて, 交差点部の 観測滞留長と区域内の観測平均旅行時間の視点で, 構築する交通ミクロシミュレーションモデルの妥当 性を確認する.

f) b)，c)により推定された3つの渋滞時OD交通量と，e) で妥当性が確認された交通ミクロシミュレーション データを用いて, 推定された3つの渋滞時OD交通量 の動的な解析への適用性を検証する.

\section{6. 渋帯時OD交通量の推定}

\section{（1） 既存OD交通量による渋滞時OD交通量の推定}

既存OD交通量による渋滞時のOD交通量は，既存のセ ンサス OD交通量(H17観測值) と PTOD交通量(H19観測值) を使用し，8:00〜 9:00における観測交通量と日交通量の 比率(ピーク率)を乗じて渋滞時OD交通量を推定した.

また, 交通の発生地点から各到達地点への到達確率は, 既存OD交通量の到達確率を採用した。 なお，ここで言 う到達確率は, ある発生地点における総発生台数に対す る各到達地点に到達する各々の台数の比率を言う.

\section{（2）渋帯時OD交通量の時点修正}

上記に示寸既存 $\mathrm{OD}$ 交通量による輆滞時OD交通量は, H17もしくはH19に観測されたものである.これらは, H22の需要と異なると考えられるため, 時点修正を行う. 
時点修正では, H22観測交通量を制約条件として, OD交通量の調整に多くの実績がある残差平方和最小化 モデルとエントロピー最大化法の比較を行った.

比較の結果, 残差平方和最小化法はエントロピー最大 化法より相関係数が高かったため, 残差平方和最小化法 による推定OD交通量を採用した.

\section{（3） GA吸収マルコフ連鎖によるOD交通量推計}

安藤ら ${ }^{33}$ により提案されているGA吸収マルコフ連鎖 $\mathrm{OD}$ 交通量推計手法を用いた. ビデオ解析による各交差 点の分岐率(右左折直進率)を用い，GAにより発生交通量 と吸収率を内生的に設定し, OD交通量を推定した.

\section{7. 推定OD交通量の静的な検証}

\section{(1) 観測OD交通量と推定OD交通量の比較}

観測により得られたOD交通量と, 先述する時点補正 した既存OD交通量およびGA吸収マルコフ連鎖による推 定OD交通量を単純比較した．表-3に示すとおり，GA吸 収マルコフ連鎖による推定 $\mathrm{OD}$ 交通量が観測ODに最も近 似していると考えられるが，観測OD交通量と各推定OD 交通量との相関係数は非常に高く, 平均 2 乗誤差平方根 (RMSE)も小さいものであった. よって, 推定されたOD 交通量は，いずれも現況に近似したものと言える.

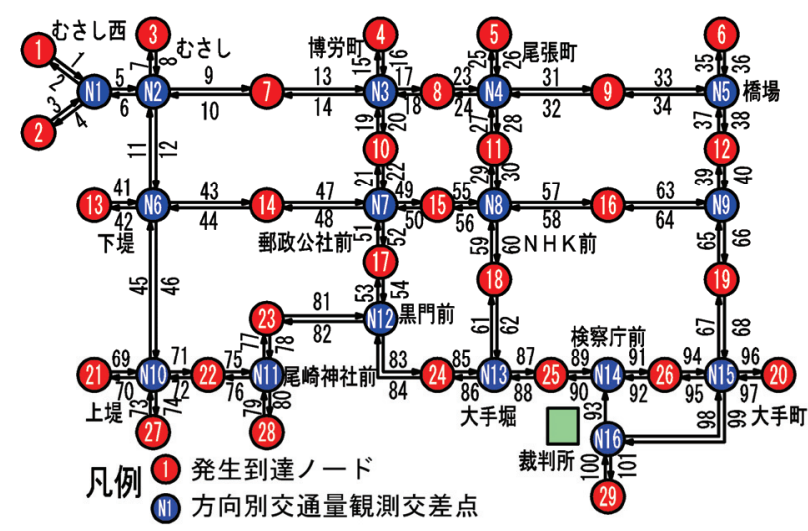

図-2 交通量配分モデル困

表-3 観測OD交通量と推定OD交通量の相関表

\begin{tabular}{|c|c|c|c|}
\hline $\begin{array}{l}\text { 使用OD } \\
\text { 交通量 }\end{array}$ & センサス & PT & マルコフ \\
\hline 観測数值 & \multicolumn{3}{|c|}{$\begin{array}{l}\text { 発生・到達ノード数 }=29 \\
\text { 総OD交通量=8,115台 } / \mathrm{h} \\
\text { OD ゚アア交通量 }=0 \sim 584 \text { 台 } / \mathrm{h} \\
\text { 平均ODペア交通量 }=10 \text { 台 } / \mathrm{h}\end{array}$} \\
\hline 相関係数 & 0.927 & 0.938 & 0.998 \\
\hline RMSE & 18.1 & 16.8 & 4.1 \\
\hline
\end{tabular}

\section{（2）静的な解析による推定OD交通量の検証}

静的に推定したOD交通量と図-2に示寸検討対象地区 の交通量配分モデルを作成し，静的な解析である利用者 均衡配分法により上下線別101リンク(51路線)の観測時間 帯(1時間)における推定交通量を算出し, 観測交通量と の再現性を検証した(表-4参照).

表-4より，いずれの OD交通量推定手法でも相関係数 は高く, RMSEも比較的小さく, OD交通量推定手法の 違いによる配分交通量の差異はほとんど見られなかった。

この原因は，もともと各路線の観測交通量と推計交通 量が近似寸るように推定したOD交通量であるため, 改 めて静的解析を行っても, その結果は観測值と近似する.

\section{8. 静的に推定されたOD交通量の動的解析への適 用性検証}

（1） 交通ミクロシミュレーションモデルの妥当性確認

動的な解析は, 図-3に示寸調査対象区域において Aimsunによる交通ミクロシミュレーションを行う．検証 に先立ち, 各路線の方向別平均旅行速度, およびむさ

表-4 観測交通量と静的交通量配分による推定交通量の相関表

\begin{tabular}{|c|c|c|c|c|c|c|}
\hline & \multirow{2}{*}{$\begin{array}{l}\text { 使用 OD } \\
\text { 交通量 }\end{array}$} & \multicolumn{3}{|c|}{ 交通量(台/h) } & \multirow{2}{*}{$\begin{array}{l}\text { 相関 } \\
\text { 係数 }\end{array}$} & \multirow{2}{*}{ RMSE } \\
\hline & & 最小 & 最大 & 平均 & & \\
\hline \multirow{4}{*}{$\begin{array}{l}\text { 断面 } \\
\text { 交通量 }\end{array}$} & 観測值 & 63 & 2,723 & 875 & 0.990 & 130.2 \\
\hline & センサス & 82 & 2,770 & 962 & 0.979 & 158.0 \\
\hline & PT & 83 & 2,917 & 967 & 0.974 & 176.4 \\
\hline & マルコフ & 26 & 3,032 & 907 & 0.986 & 151.6 \\
\hline \multirow{4}{*}{$\begin{array}{l}\text { 上り線 } \\
\text { 交通量 }\end{array}$} & 観測值 & 0 & 1,265 & 384 & 0.982 & 72.4 \\
\hline & センサス & 0 & 1,350 & 447 & 0.937 & 159.4 \\
\hline & PT & 0 & 1,303 & 438 & 0.945 & 143.2 \\
\hline & マルコフ & 0 & 1,412 & 382 & 0.963 & 110.8 \\
\hline \multirow{4}{*}{$\begin{array}{l}\text { 下り線 } \\
\text { 交通量 }\end{array}$} & 観測值 & 6 & 1,458 & 491 & 0.987 & 82.6 \\
\hline & センサス & 40 & 1,688 & 515 & 0.887 & 200.9 \\
\hline & PT & 31 & 1,614 & 529 & 0.909 & 184.5 \\
\hline & マルコフ & 1 & 1,727 & 525 & 0.973 & 129.3 \\
\hline
\end{tabular}

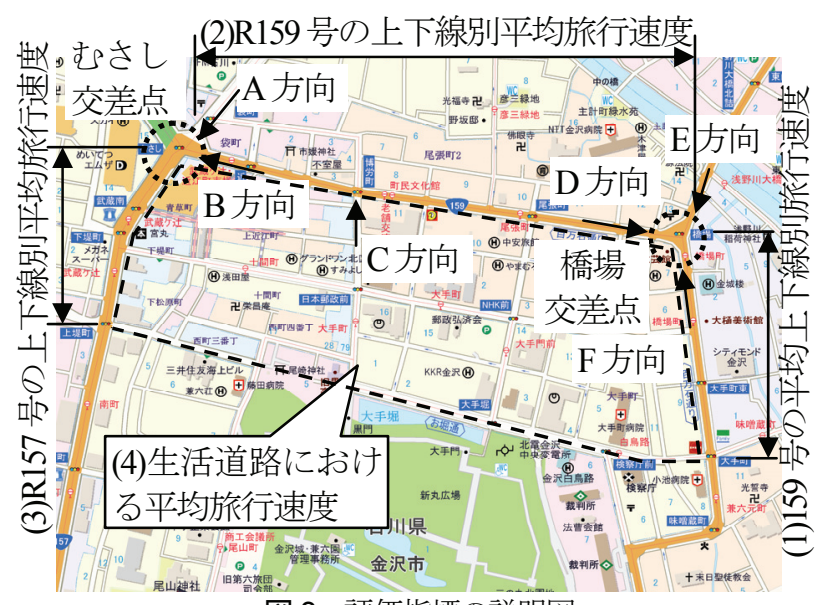
図-3評価指標の説明図 
し・橋場交差点のA〜F方向における観測時間帯最大渋 滞長を指標として，観測值と再現值の相関によりシミュ レーションデータの妥当性を確認した(表-5参照).

\section{（2）交通ミクロシミュレーションにおける適用性検証}

既存OD交通量に基づき時点補正したOD交通量および GA吸収マルコフ連鎖によるOD交通量と, 妥当性を確認 した交通ミクロシミュレーションデータから静的推計 $\mathrm{OD}$ 交通量の動的解析への適用性を検証した結果を以下 に示寸.

\section{a) 平均旅行速度の検証}

平均旅行時間においては，使用するOD交通量による 差異はほとんど見られなかった(表-6参照).

b) むさし・橋場交差点の観測時間帯最大渋滞長の検証 むさし・橋場交差点のA〜F方向における観測時間帯最 大渋滞長の観測值と解析結果を表-7, 図-4, 図-5に示寸。

表-5 交通ミクロシミュレーションデータの妥当性確認

\begin{tabular}{|c|c|c|c|c|}
\hline \multirow{2}{*}{$\begin{array}{l}\text { 使用OD } \\
\text { 交通量 }\end{array}$} & \multicolumn{2}{|c|}{ 旅行時間(分) } & \multicolumn{2}{|c|}{ 最大渋滞長 $(\mathrm{m})$} \\
\hline & 相関係数 & RMSE & 相関係数 & RMSE \\
\hline 観測数値 & \multicolumn{2}{|c|}{$\begin{array}{c}\text { 旅行時間 }=0.9 \sim 21.9 \\
\text { 平均值 }=5.0\end{array}$} & \multicolumn{2}{|c|}{$\begin{array}{c}\text { 渋滞長 }=75 \sim 260 \\
\text { 平均値 }=157.5\end{array}$} \\
\hline 観測値 & 0.998 & 1.1 & 0.981 & 16.9 \\
\hline
\end{tabular}

表-6 平均旅行時間の比較表 単位 分

\begin{tabular}{|c|c|c|c|c|c|c|}
\hline \multirow{2}{*}{$\begin{array}{l}\text { 路 } \\
\text { 線 }\end{array}$} & \multirow{2}{*}{ 方向 } & 観測平均 & \multicolumn{4}{|c|}{ 使用OD交通量 } \\
\hline & & 旅行時間 & 篗賏值 & センサス & PT & マルコフ \\
\hline \multirow{2}{*}{ (1) } & 上り & 0.92 & 0.9 & 1.1 & 0.9 & 0.9 \\
\hline & 下り & 0.89 & 0.8 & 1.1 & 0.9 & 0.8 \\
\hline \multirow{2}{*}{ (2) } & 上り & 4.6 & 3.2 & 2.8 & 2.6 & 2.6 \\
\hline & 下り & 4.1 & 3.1 & 2.3 & 2.4 & 2.7 \\
\hline \multirow{2}{*}{ (3) } & 上り & 1.5 & 1.5 & 1.2 & 1.1 & 1.1 \\
\hline & $\begin{array}{l}\text { 下り } \\
\end{array}$ & 0.89 & 0.6 & 0.6 & 0.6 & 0.6 \\
\hline (4) & 上下 & 21.9 & 19.7 & 24.0 & 18.1 & 17.7 \\
\hline
\end{tabular}

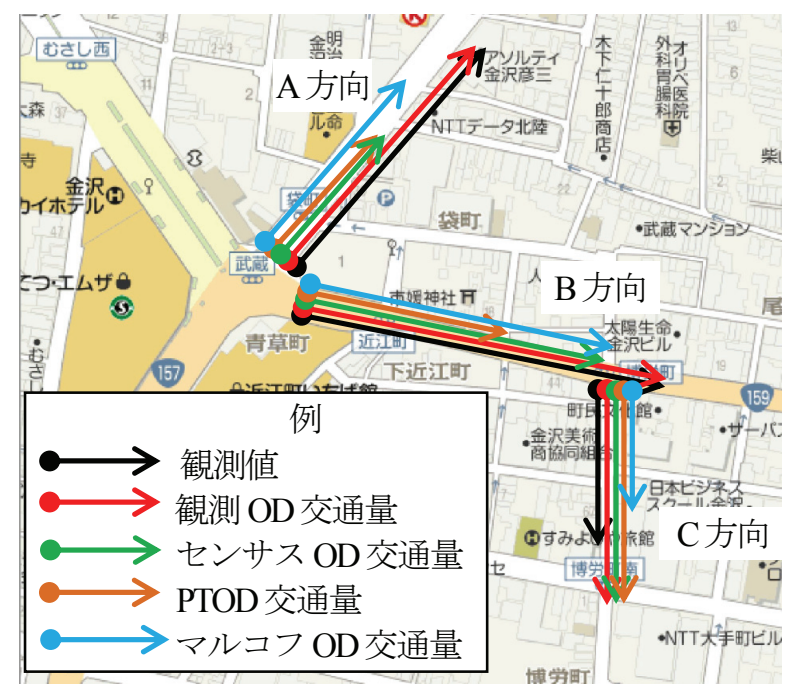

図-4 むさし交差点における観測時間帯最大渋滞長図
解析の結果，観測時間帯最大渋滞長は使用寸るOD交 通量により再現性の精度の差異が生じており, GA吸収 マルコフ連鎖による推計OD交通量が観測值に最も近い 結果であった.

以上より，静的に推定した既存 $\mathrm{OD}$ 交通量を基に時点 補正した推定OD交通量と吸収マルコフ連鎖による推定 $\mathrm{OD}$ 交通量を動的な解析である交通ミクロシミュレーシ ヨンに使用した場合, 平均旅行時間では大きな差異が認 められなかったが，渋滞の指標となる渋滞長ではその再 現性が異なり，GA吸収マルコフ連鎖による推計ODの再 現性が高かった。

\section{9. 研究結果のまとめと今後の課題}

\section{（1）ヘリコプターを利用したOD交通量観測}

本研究では，OD交通量観測で一般に用いられるアン ケートやナンバープレート調査ではなく, ヘリコプター を用いて空撮を行い，録画したビデオから $\mathrm{OD}$ 交通量の 計測を行った。

当該手法は, 現地調査員が不要であるため安全性が 高く, 調查は容易に行うことが可能であり, 精度も高 いものであるため実務的に有用であると考えられる。

ただし, ヘリコプター空撮によるOD交通量調査には

表-7 観測時間帯最大渋滞長の比較表 (単位 : m)

\begin{tabular}{|c|c|c|c|c|c|c|}
\hline \multirow{2}{*}{$\begin{array}{c}\text { 交 } \\
\text { 差 } \\
\text { 点 }\end{array}$} & \multirow[b]{2}{*}{ 方向 } & \multirow{2}{*}{$\begin{array}{l}\text { 観測 } \\
\text { 渋滞長 }\end{array}$} & \multicolumn{4}{|c|}{ 使用 OD交通量 } \\
\hline & & & 観測值 & センサス & PT & マルコフ \\
\hline \multirow{3}{*}{$\begin{array}{l}\text { d } \\
\text { ¿ } \\
\text { L }\end{array}$} & A & 230 & 230 & 130 & 130 & 170 \\
\hline & $\mathrm{B}$ & 260 & 260 & 240 & 140 & 240 \\
\hline & $\mathrm{C}$ & 80 & 100 & 100 & 100 & 70 \\
\hline \multirow{3}{*}{$\begin{array}{l}\text { 橋 } \\
\text { 場 }\end{array}$} & $\mathrm{D}$ & 180 & 155 & 110 & 110 & 140 \\
\hline & $\mathrm{E}$ & 75 & 95 & 95 & 110 & 75 \\
\hline & $\mathrm{F}$ & 120 & 120 & 180 & 160 & 120 \\
\hline
\end{tabular}

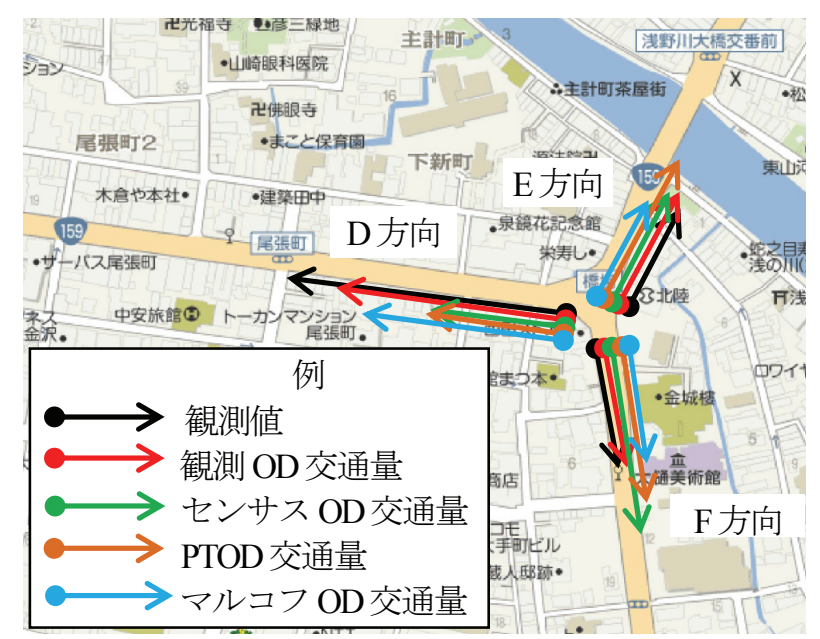

図-5＼cjkstart橋場交差点における観測時間帯最大渋滞長図 
限界があるため, 次に示す条件を満たすOD交通量調査 においてのみ適用可能である。

・観測範囲が比較的狭い範囲であること(約20ha機).

・観測時間が短いこと(1時間程度).

・調査時間帯は, ヘリコプターが運航できる時間帯 (日の出から日没までの時間帯)で，しかもホバーリ ングか可能な風のない日中の時間帯であること.

(曇りの場合は, ビデオ画像が読みにくいので, で きれば晴天時が望ましい)

・調査結果の集計に多大な時間と労力が必要であり, 集計期間と労力が確保されていること.

また，当該調査の実施にあたっては，関係機関への周 知を図る必要がある.

\section{（2）静的推定OD交通量の動的解析への適用性の検証}

本研究では, 既存OD交通量（センサスOD交通量と PTOD交通量）に基づき時点補正された渋滞時のOD交通 量と, GA吸収マルコフ連鎖によるOD交通量を推定し, 動的な解析である交通ミクロシミュレーションに対する 静的に推定されたOD交通量の適用性を研究した.

渋滞の目安となる旅行時間と交差点の渋滞長を指標と して，使用するOD交通量の違いによる再現性の差異に ついて研究を行った結果, 静的な解析 (利用者均衡配 分）ではほとんど差異は見られず，交通ミクロシミュレ ーションでも旅行時間では差異がみられなかった。

しかし，表-8に示す通り，交差点の渋滞長では，使用 するOD交通量の違いにより再現性が大きく変わり，GA 吸収マルコフ連鎖による推計OD交通量が最も再現性が 高かった。この原因は，既存OD交通量による推定OD交 通量は，各路線の観測交通量に基づきOD交通量を推定 しているため平均旅行速度は現実に近似するが，GA吸 収マルコフ連鎖による推計手法は，交通量と交差点の分 岐率に基づくため，交差点における経路選択が現実に近 く, 現況の交通行動を推計OD交通量に反映しているた めと考えられる.

\section{（3） 今後の課題}

ヘリコプター空撮による観測結果の集計において多大 な時間と費用を要するため, 今後は画像処理ソフト(動 画内の特定点を追跡するソフト)の開発で省力化とコス

表-8 旅行時間・観測時間帯最大渋滞長における相関表

\begin{tabular}{|c|c|c|c|c|}
\hline \multirow{2}{*}{$\begin{array}{c}\text { 使用OD } \\
\text { 交通量 }\end{array}$} & \multicolumn{2}{|c|}{ 旅行時間(分) } & \multicolumn{2}{|c|}{ 最大渋滞長 $(\mathrm{m})$} \\
\cline { 2 - 5 } & 相関係数 & RMSE & 相関係数 & RMSE \\
\hline 観測值 & 0.998 & 1.1 & 0.981 & 16.9 \\
\hline センサス & 0.993 & 1.3 & 0.638 & 62.1 \\
\hline PT & 0.996 & 1.8 & 0.388 & 60.2 \\
\hline マルコフ & 0.997 & 1.8 & 0.963 & 32.6 \\
\hline
\end{tabular}

ト削減が望まれる.

静的OD交通量推計手法において, 本研究では推定し たOD交通量をそのまま交通ミクロシミュレーションに 代入したが，ミクロシュミレーションによるキャリブレ ーション(補正)を繰り返し行い，旅行時間や渋滞長を指 標として観測值と推定值の整合により推定OD交通量の 精度向上を図ることが必要と考える.

謝辞 : 本研究で使用したデータは, 金沢河川国道事務所 のご厚意により，貴重な空撮ビデオデータの提供をいた だいた.ここに記して，感謝を申し上げる.

\section{参考文献}

1) Van Zuylen, H. J. and Willumsen, L. G.: The most likely trip matrix estimated from traffic counts, Transpn. Res. B, Vol.14B, pp.281-293, 1980.

2) Van Vliet, D. and Willumsen, L. G.: Validation of the ME2 model for estimating trip matrices from traffic Counts, Proceedings of the 8th International Symposium on Transportation and Traffic Theory, 1981.

3) 飯田恭敬, 高山純一, 小林光二：リンク観測交通量 を用いたエントロピー最大化による道路網交通需要 推計法, 土木計画学研究・講演集, No.9, pp.441-448, 1986.

4) 高山純一, 飯田恭敬：リンク観測交通量を用いた残 差平方和最小化による交通需要推計法, 第 40 回土木 学会年次学術講演概要集, 第 IV 部, pp.407-408, 1985.

5) 飯田恭敬, 高山純一：リンクフローによる OD 交通 量推計モデル, 第 18 回土木計画学講習会テキスト, pp.97-118, 1987.

6) 飯田恭敬：発生交通量のみを変量とした実測交通量 による交通需要推計法, 土木学会論文報告集, 第 283 号, pp.95-104, 1974.

7) Dial, R. B.: A probabilistic multipath traffic assignment Model which obviates path enumeration, Transpn. Res., Vol.5, pp.83-111, 1970.

8）飯田恭敬, 高山純一, 金井一二, 水口玲二：Dial 確 率配分法を導入したリンク交通量による道路構交通 需要推計法, 都市計画別冊, 第 19 号, pp.13-18, 1984.

9) 飯田恭敬, 高山純一：リンクフロー観測值を用いた 一重制約型重力モデルによる OD 交通量推計法, 交 通工学, Vol.26, No.1, pp.27-29, 1991.

10）立石亮祐, 寺澤善理, 渡辺義則：観測交通量による OD 交通量の簡便的な時点修正に関する検討, 第 29 回交通工学研究発表会論文集, No.60, pp.237-240, 2009.

11）前田友宏, 飯田恭敬, 倉内文孝, 上坂克巳 : B ゾー ンベースによる OD 交通量逆推定モデルの実際適用 性, 第 29 回交通工学研究発表会論文集, No.61, pp.241-244, 2009.

12) Low, D. E.: A new approach to transportation systems modeling, Traffic Quarterly, pp.391-404, 1972.

13) Jensen, T. and Nielsen, S. K.: Calibrating GA gravity model and estimating its parameters using traffic volume counts, Proceeding from the English University Traffic Engineer's yearly congress, 1973. 
14) Holm, J., et al.: Calibrating traffic models on Traffic census results only, Traffic Engineering and Control, Vo1.17, No.4, pp.137-140, 1976.

15) 井上博司：交通量調査資料を用いた OD 交通量の統 計的推計法, 土木学会論文報告集, 第 332 号, pp.8594, 1983.

16) 佐佐木綱 : 吸収マルコフ過程による交通量配分理論, 土木学会論文集, No.121, pp.28-32, 1965.

17) 米谷栄二, 前島忠文：連続マルコフ過程による交通 量の時間的変化についての考察, 交通工学, No.5, Vol.2, pp.11-16, 1967.

18) 米谷栄二, 佐佐木綱, 西藤立雄 : マルコフ連鎖によ る OD 交通量の推定, 土木学会論文集, No.129, pp.15-22, 1966.

19) 大矢正樹：吸収マルコフ連鎖を利用した交通規制実 施の影響評価, 土木計画学研究・講演集, Vol.4, pp.430-433, 1982.

20) 西井和夫, 古屋秀樹，坂井努：時間軸を考慮したマ ルコフ連鎖モデルによる観光周遊行動分析, 交通工 学, Vol.5, No.17, pp.21-30, 1996.

21）高山純一, 足立義幸, 飯田恭敬：遺伝的アルゴリズ ムを用いた吸収マルコフ連鎖による観測交通量から の簡易 OD 推計法, 土木学会年次学術講演会講演概 要集 第 4 部, Vol.49, pp.754-755, 1994.

22）杉山智美，高山純一，藤岡寛之：GA を用いた吸収マ ルコフ連鎖による観測交通量からの簡易 OD 推計法 の適用性, 土木学会年次学術講演会講演概要集 第 4 部, Vol.50, pp.142-143, 1995.

23）高山純一，杉山智美：吸収マルコフ連鎖を用いた観 測交通量からの OD 推計法に関寸る研究, 土木学会 論文集，No.569/IV-36, pp.75-84, 1997.

24) 高山純一, 中山晶一朗, 八木基徳, 赤松隆: サイク リック経路を除去した吸収マルコフモデルによる OD 交通量推計に関寸る研究, 土木学会年次学術講演会 講演概要集 第 4 部, Vol.60, pp.4-28, 2005.
25）鈴村哲矢, 高山純一, 中山晶一朗, 赤松隆 : LOGIT 型配分による吸収マルコフ連鎖を用いた OD 交通量 推計に関する研究, 土木計画学研究発表会・講演集, Vol.33, 2006.

26）鈴村哲矢, 高山純一, 中山晶一朗, 赤松隆 : 吸収マ ルコフ連鎖を用いた OD 交通量推計の誤差に関する 研究, 土木計画学研究発表会・講演集, Vol.34, 2007.

27) 交通工学研究会：やさしい交通シミュレーション, pp.4, 2000.

28) 前沢浩史, 森本章倫, 古池弘隆 : 交通シミュレーシ ヨンを用いた観光地の渋滞発生要因に関する研究, 土木学会関東支部技術研究発表会講演概要集, Vol.29, pp.604-605, 2002.

29) 羽藤英二, 三谷卓摩, 江川雅代 : 災害情報システム へのミクロ交通シミュレーションの導入とその方向 性, 土木計画学研究発表会・講演集, Vol.28, VII-204, 2003.

30) 花房比佐友, 高橋勝美, 堀口良太 : 中心市街地の交 通施策検討における動的交通シミュレータの適用, 土木学会年次学術講演会講演概要集 第 4 部, Vol.55, pp.880-881, 2000.

31) 高島一彦, 古池弘隆, 森本章倫：ミクロ交通シミュ レーションによる交差点部の安全性評価に関する研 究，土木情報利用技術論文集，Vol.12，pp.227-236， 2003.

32）飯田裕三, 森津秀夫, 三谷哲雄, 野寺寿雄 : ミクロ 交通シミュレーションの参加型交通計画への適用, 土木計画学研究・講演集, No.285, 2002.

33) 安藤正幸, 高山純一, 中山晶一朗 : 金沢市における 現実道路ネットワークへの適用を図る改良吸収マル コフ連鎖 OD 推計法の実施例, 土木計画学研究・論 文集，Vol.27, No.3, pp.463-474, 2010.

(2012. 2. 25 受付)

\title{
EXAMPLE OF OD TRAFFIC VOLUME SURVEY BY A HELICOPTER AND VERIFICATION OF THE APPLICABILITY OF STATIC ESTIMATED OD TRAFFIC VOLUME WITH RESPECT TO THE DYNAMIC ANALYSIS
}

\author{
Masayuki ANDOU, Jun-ichi TAKAYAMA, Sho-ichiro NAKAYAMA, \\ Masao KUWAHARA and Masahiro RACHI
}

It is necessary to understand the traffic demand (OD traffic volume) at the time of congestion in the urban area in order to do the congestion easing and the transportation demand management. So far, in order to grasp the traffic demand, the observation of license plate primarily has been used, but the observer's safety management was a problem. In this study, the OD traffic volume by the aerial video filming of the helicopter that did not need the investigators in the investigation site was observed, and the feature of this survey method was arranged.

Moreover, a lot of estimation methods of the OD traffic volume at the time of congestion have been researched so far. In this study, after the statical estimation of the OD traffic volume at the time of congestion by the existing OD traffic volume estimation technique, the applicability to dynamic analysis of a statical method of OD traffic volume estimation is verified with using the traffic micro simulation that is used in various dynamic analysis recently. 